\title{
Commodity and Food Speculation, Is There a Need for Regulation? A Discussion of the International Research
}

\author{
Christian A. Conrad ${ }^{1}$ \\ ${ }^{1}$ University of Applied Science HTW at Saarbrücken, Germany. \\ Correspondence: Christian A. Conrad, University of Applied Science HTW, Waldhausweg 14, 66123 Saarbrücken, \\ Germany.
}

Received: September 10, 2014

doi:10.11114/aef.v1i2.548
Accepted: October 5, 2014

Available online: October 9, 2014

\begin{abstract}
Much empirical research has already been conducted in order to analyze how speculation affects commodity and especially food prices. This paper examines the effects of speculation based on the most recent research. It is time to break with the innumerable studies examining the same material, yet always reaching different conclusions. Investigations using econometrics prove neither an influence of speculation on prices, nor the contrary. This paper explains however that speculation influences spot prices of commodities and food if it creates a significant excess demand over a significant time period. In this case speculation might be seen as harmful and unethical, why regulation should be discussed.
\end{abstract}

Keywords: Financial markets, speculation, commodities, food, econometric research

JEL Classification: G13, Q11, Q31

\section{Introduction}

For some time now, there has been an intensive discussion about the effects of speculation with commodities, in particular with agricultural products. The following paper examines the effects of speculation based on the most recent research. The following questions will be addressed: Will futures prices and price volatility be influenced by speculation? Would that create false price signals, and if yes, what effects will that have? In specific will there be demand effects for the spot market prices, which would increase the living costs thus could be seen as unethical?

\section{What Empirical Evidence Do We Have About Speculation Influencing Markets?}

Many empirical studies show a relationship between speculation on futures markets and the price development of goods affected on the cash markets, as well as the volatility of prices for goods. Gilbert (2010) shows, for example, the relationship between index-based investments and the prices for foods, and uses it to explain the exorbitant price increases from 2007 to 2008. This connection, and the peak in food prices from 2010 to 2011, was also shown by Lagi, Yavni Bar-Yam, Betrand and Yaneer Bar-Yam (2011a) in a comprehensive model that included surveys for merchants and producers. These papers show that in their respective time frames, speculation caused prices to be about $50 \%$ above the level that would have been appropriate for the physical demand and supply. Their results have been checked by other researchers from Harvard University and the Federal Reserve Bank of Boston. Many other studies arrive at the same conclusions (Deutsche Bundesbank 2006; Gilbert 2010; Singleton 2011; Chilto 2012). Mayer (2009) points out the influence from various types of speculation on commodity prices.

Pies (2012) offers a contradictory argument, namely that the prices for commodities also rose within the same time periods, yet they were not the object of index-fund speculation or even traded on futures markets. Unfortunately, Pies does not offer proof of this assertion, nor does he name what commodities he used. It cannot be concluded from this however, that there was no effect from index speculation until long-term correlations between these commodities have been examined, eliminating phenomena such as a price transfer substituting non-indexed commodities for indexed commodities (cross-price elasticity). There are also investors who speculate on increasing commodity prices outside of index funds, thus buying non-indexed commodities forward or investing in long futures. 
In a study from 2009 the United States Permanent Subcommittee on Investigations, concluded that from 2006 to 2008 investments in index funds inflated grain futures prices in relation to the spot prices on the Chicago stock market (Levin $\&$ Coburn, 2009).

"This Report finds that there is significant and persuasive evidence to conclude that these commodity index traders, in the aggregate, were one of the major causes of "unwarranted changes"- here, increases - in the price of wheat futures contracts relative to the price of wheat in the cash market. The resulting unusual, persistent, and large disparities between wheat futures and cash prices impaired the ability of participants in the grain market to use the futures market to price their crops and hedge their price risks over time, and therefore constituted an undue burden on interstate commerce." (Levin \& Coburn, 2009)

This study was contested by Stoll and Whaley (2009), which was funded by Gresham Investment Management LLC. Stoll and Whaley test index fund inflows for any influence on futures prices. In contrast to other studies, they do not find any significant connection between index fund investments and commodity price increases, however, they only take the large positions reported in the COT Report and only the positions of index funds into account. In addition, the objectivity of this study must be questioned, since financial positions in commodities are key business of Gresham. Neither did Irwin and Sanders (2010) determine increased prices nor increased volatility on futures markets for commodities as a result of investments in indexed commodity funds. In fact, according to their empirical research, the index investments caused decreased price volatility.

Stoll and Whaley (2009) also analyzed the development of commodity prices both in and out of the index, finding a weak correlation of between 0.13 and 0.20 in both cases. They found a similarly weak correlation to index commodities for commodity prices outside of the indexes. From these findings they conclude that the index investments had no effect on the prices. Tang and Xiong (2012) calculated however, that there was no correlation (less than 0.1) between indexed commodities in the 1990s and early 2000s. The same was true among non-indexed commodities. In 2009 however, the correlation among indexed commodities increased to over 0.5 , while the correlation for non-indexed commodities only increased to 0.2. This result can be traced back to the influence of index investments. The prices for indexed and non-indexed commodities developed differently between 2004 and 2008. The indexed commodities increased evenly in that period then fell, which did not reflect fundamental changes in supply and demand, rather in the flows of investment capital. The other commodities developed very differently. The same increase in demand for various products can have differing effects on prices if the supply elasticity differs. The market power on the supply side would also need to be considered, such as the OPEC cartel on the oil market.

Stoll and Whaley (2009) also offer the argument that the shifts in futures positions before the phase-out would have led to significant jumps in prices if the index investors had influence over pricing, which was not the case. We can counter however, that the opposing positions must phase-out and be extended as long as we are not talking about a physical delivery that has been agreed upon. Bass (2011) points out that the investors keep their demand constant by rolling over their contracts.

At bottom Stoll and Whaley (2009) contradict the Subcommittee and do not consider the functionality of futures markets to have been restricted by index investments because only 3\% of the contracts from 2005 to 2009 were physically fulfilled, and thus could not have influenced the spot market. This also means that the differences from spot prices are not due to index investments. However this does not mean that the futures prices were not positively influenced, however. 97\% non-physically fulfilled contracts indicate a large influence of non-commercial goods.

Supporters of speculation offer other causes for the increase in food prices from 2007 to 2008. Irwin and Sanders (2010) argue that the greatly increased demand for commodities from China, India and other emerging markets, interruptions in oil production, less demand elasticity in consumers and US monetary policy were all causes of the price increases. Given the negative correlation between the real interest rate and commodity prices, Inamura, Kimata, Kimura and Muto (2011) conclude that too light of a US monetary policy supported the boom in commodity prices. The increased cost of biofuels and weather were given as causes for the increased grain prices (Irwin \& Sanders, 2010). Frenk (2011) counters that although the Chinese demand for oil rose by $12 \%$ in 2008, Europe and the US entered a recession that brought the international demand for oil down. In fact oil supply increased in the first 6 months of 2008, which makes an increase in oil prices of 50\% within the same time period inexplicable. Baffes and Haniotis (2010), like Lagi, Yavni Bar-Yam, Betrandand and Yaneer Bar-Yam (2011b), come to the conclusion from their study that neither the demand from emerging economies nor from biofuel production contributed significantly to the price boom in foods, rather that it was the demand from finance investors. Inamura (2011) also considers weather, tensions in the Middle East, and in particular the economic boom in emerging economies (output gap) insufficient to explain the large increase.

The hedge fund manager Masters (2009) points out that neither the absolute increases of future oil prices before the financial crisis, nor the slump that followed, had been seen before: 
"In fact, the volatility of the last two years has never been seen before in history. First, prices doubled from $\$ 70$ to $\$ 140$ in twelve months. Then they crashed from $\$ 140$ to $\$ 35$ in the next six months. Then they doubled again from $\$ 35$ to $\$ 70$ in the six months after that. All of this with not a single major disruption to oil supplies anywhere in the world."

In the end the slump in commodity prices after 2008 can only be explained by the lapse in speculation demand resulting from the financial crisis, since all other factors remained constant.

Inamura (2011) found an increasing correlation between commodities and other forms of investment since 2005, and considers it to be an expression of the increased financialization of commodity markets by finance investors. The commodity markets reflect the same liquidity flows in this period as the stock markets. This is indeed an important observation, as the negative correlation is a main reason investors in commodities would diversify and thus reduce the risk of the portfolio as a whole (Markowitz, 1952).

High futures prices induce a replenishing of stocks and an increase of storage capacity. Without high futures prices there would be no sure basis for the calculation of profit from commodity stocks, making it purely speculative. The higher future prices are, the higher the assured profits will be. Krugman (2011, February 7) therefore sees an influence of futures prices on spot prices only via arbitrage, thus a scarcity in spot offers due to stock holding with a view to selling at higher future prices. He only sees this effect with copper and cotton however, not for agrarian products whose stock holding did not increase.

For agrarian markets Will, Prehn, Pies and Glauben (2012) used wheat to determine a decline in stock keeping until 2008. He admits that the data are incomplete however, since private stocks were not registered. Nonetheless, if storage capacities did not increase there is not necessarily anything we can conclude. If the investment costs for new storage capacity are high, futures prices must exceed spot prices for a longer time in order to make the investment worthwhile.

\section{Critique of Methodology}

Within the discussion both sides criticize one another's methodological weaknesses in econometric studies based primarily on Granger. Irwin and Sanders' results are criticized based on the fact that the Granger test is not an appropriate method with highly volatile variables, thus distorting results (Frenk, 2012). The problem is of a more fundamental nature, however. If causal variables are not eliminated, false correlations can show up in Granger tests (spurious regression). The same is true for purely coincidental correlations, which can show up particularly in short time periods of observation.

As we have already shown, many speculation proponents argue that the greatly increased demand for commodities from China, India and other emerging economies, interruptions in oil production, less consumer demand elasticity and US monetary policy were all responsible for the price increases. Increased biofuel production and weather were considered to have caused the price increases (Irwin \& Sanders, 2010). If so many factors were truly affecting prices and the Granger test would not have been applicable due to multi-causality. The same is true for the effects of weather, since the required stationarity of variables would not be given (Schulze, 2004; Hassler, 2003). Highly volatile variables such as stock prices or commodities prices were also determined to have insufficient covariant stationarity, thus the requirement for the regression of time series is not met (Pagan \&Schwert, 1990; Phillips \&Loretan 1990; Frenk 2011; Schlecker, 2014).

Irwin and Sander have been criticized for using lags of one week whereby price influences are exceeding one week, as well as for using non-representational data (Frank 2011). The same is true for the Stoll and Whaley study. The positions of the index funds are not transparent because the DCOT Swap Dealer Data also contains positions from other market participants. The Commodities Futures Trading Commission (CFTC) estimates in fact that only $41 \%$ of the positions for crude oil futures belong to the index funds (Frenk 2011; Masters \& White, 2008). This represents a general problem. The quality of the data is also questionable, since it is generally based on questionnaires or is incomplete:

"There have been ongoing complaints that the legacy COT trader designations may be inaccurate ... As one example, speculators may have an incentive to self-classify their activity as commercial hedging to circumvent speculative position limits in some markets. But, the CFTC implements a fairly rigorous process-including statements of cash positions in the underlying commodity - to ensure that commercial traders have an underlying risk associated with futures positions. However, in recent years industry participants began to suspect that these data were contaminated because the underlying risk for many reporting commercials was not a position in the physical commodity... Rather, the reporting commercials were banks and other swap dealers hedging risk associated with over-the-counter (OTC) derivative positions." (Irwin \& Sanders, 2012; Frenk, 2011).

OTC derivatives were not even required to be posted in the time periods examined. Only after the financial crisis it was decreed that derivatives had to be registered or dealt via clearing houses (Conrad, 2013). 
According to the scientists of the Raiffeisen Association the majority of empirical studies show no verifiable connection between stock volumes and the price increase:

"Quite the opposite, the large majority of papers written on this topic to date - though also based on suboptimal futures market data sets - come to the conclusion that there no causal connection exists between stock volumes and price increases." (Petersen, Herlinghaus, \& Menrad, 2012, translation by the author).

The NGO WEED disagrees and lists over 100 empirical studies that are critical of speculation (Weed, 2013). The economic ethicist Pies examined 35 studies and concluded that no negative effect from commodity speculation could be proven (Will, Prehn, Pies, \& Glauben, 2012).WEED accuses Pies of not examining important studies critiquing speculation and having biased criticism against the methodology used in studies critical of speculation (Henn, 2013).

Irwin reviews the evidence from recent studies and argues that "the growing body of literature fails to find compelling evidence that buying pressure from commodity index investment in recent years caused a massive bubble in agricultural future prices." (Irwin, 2013).

Both positions are in fact supportable using the empirical studies that have been conducted. One part of the studies shows that speculation has influenced commodity prices and the other part proves the opposite. We see here the dilemma of econometric research. There is no proof of causality, as there can be many factors behind a correlation.

After innumerable studies examining the same thing and coming to different conclusions, it is time to make a change. It is clear that using econometrics proves neither the influence of speculation nor its absence. Additional studies will not change that fact. The two camps of advocates and critics of speculation are still at a draw. Logic should therefore be used as an alternative economic method to analyze the effects of commodity speculation based on known and widely accepted facts.

\section{The Logic of Speculation}

Stoll and Whaley argue that investment in commodities is no different than invest in stocks, for example. They fail to note however, that the money flowing into commodities is not productive. No production sites are financed, as may be the case with stocks. Commodity investments do not increase the growth of a national economy. There is also no direct offset for scarcities, such as arbitrage and thus making the most of spatial price differences. An investment in commodities is always in the expectation of future price increases and is therefore speculation. Even if the motivation is to diversify a portfolio, the investor still expects increasing commodity prices. Prices may increase due to scarcity, but there are other causes such as cost increases and inflation. As the utilization of spatial price differences, speculation can balance out future imbalances between supply and demand if the speculation demand leads to a price increase that signals producers to increase their supply. Such a chain of events is not necessarily the case however, since the future scarcity of goods, thus prices different from current prices, is not assured. In order to divert production in the right direction, the speculators must be better informed than the market, which is not generally to be assumed. The opposite is also a possibility, namely that speculation creates a false signal for production.

Speculating at one's own risk is a fundamental part of a market-based system. New market participants entering both sides of the market through speculation by buying or selling has a stabilizing effect on prices because of the increased liquidity. Gary Cohn, Co-President, Managing Director and CEO of Goldman Sachs New York, argues in favor of allowing non-commercials because where once there were only producers that wanted to sell on futures markets to secure their interests against price fluctuations, now liquidity is available from the other side thanks to non-commercials (Cohn, 2008). With this argument Cohn is forgetting to mention the downstream users of commodities, who are the traditional buyers of commodities and agrarian products on the futures market. In addition, index investors sell differently than speculators because they buy to diversify their portfolios or they want to keep long positions in commodities and risk diversification at a certain proportion to their other stocks. Their profit orientation is also contrary to the downstream users, who want to buy at low prices. Increasing prices attract more investors.

"Traditional Speculators provide liquidity by both buying and selling futures. Index Speculators buy futures and then roll their positions by buying calendar spreads. They never sell. Therefore, they consume liquidity and provide zero benefit to the futures markets." (Masters, 2009).

Cheng, Kirilenko and Xiong also show the flip side of liquidity flow. Liquidity flowing in from non-commercials makes the goods dealt on the market fungible, but the 2008 reduction in liquidity put the market under pressure. Emerging markets experienced a similar phenomenon during the Asian crisis of 1997 (Cheng, Kirilenko, \& Xiong, 2012).

Krugman considers speculation to be a zero sum game. Every futures long contract is accompanied by a short contract, which is why he does not see any influence on prices. "Buying a futures contract for oil does not reduce the quantity of oil available for consumption; there's no such thing as "virtual hoarding"'. (Krugman, 2008, June 21). One must point out however, that the supply and demand on the spot market may not be influenced, but they are on the futures market. 
Of course a futures contract can only be concluded on the futures market if there is a short position corresponding to the long position, but excess demand will only increase prices until a market participant considers the offset lucrative. In short, if everything else says the same, an additional demand for commodities increases prices on futures markets. Even if futures prices do not influence spot prices with a supply scarcity resulting from increased stock holding, it is still possible for expectations to have an influence. Lagi et al. (2011a) have shown this: “... we interviewed participants in the spot market who state unequivocally that they base current prices on the futures market. The use of futures prices as a reference enables speculative bubbles on the futures market to influence actual food prices."

Krugman is correct in that speculation is in principle a zero sum game. What one actor wins, another must lose. In the case of commodity speculation, the speculators can fulfill an important function by buying forward the commodities from downstream users and thus reducing the risk of price changes. In such a case they fill the purpose of insurance, which also a central argument of those in favor of unimpeded speculation (Pies \& Will, 2013).

With such an argument however, we must remember that a producer can meanwhile be facing up to 4 speculators and thus speculation goes far beyond simple insurance. The speculators may buy and sell amongst one another (Domanski\& Heath, 2007), which can nevertheless lead to an increase of futures prices with excess demand. The index funds invested almost exclusively long until the peak of 2008, which created a great deal of excess demand (Stoll \& Whaley, 2009).

\section{Conclusion}

Does speculation has an effect on spot prices which would increase the living costs with unethical effects especially for poor countries? The fact is that financialization has caused new market participants to join commodities and agricultural markets with distinct economic motivations. Because the investors were interested in diversifying their portfolios, massive long positions were built up until the financial crisis. Many billions of dollars thus came into the markets as additional demand. Since the investors did not want the commodities delivered, the additional demand ad a direct influence only on futures markets, not on spot markets. This caused an increase in the secure stock profits that, as long as they were greater than the cost of storage, would lead sooner or later to a scarcity in supply and thus to increased spot market prices. We can therefore assume an influence of futures prices on spot prices if the excess demand on the futures market is high and stays high over a longer time period. If commodity and agriculture producers think futures prices are at a historic high they will sell their production forward, which removes the supply from the future spot market. Increasing prices for end and intermediate goods involving commodities and agriculture product are also possible if the downstream producers secure their positions on futures markets at a high price level. So we come to the conclusion that speculation influence spot prices of commodities and food prices if it creates a significant excess demand over a significant time period. In this case speculation might be seen as unethical, why regulation should be discussed.

\section{References}

Baffes, J., \& Haniotis, T. (2010). Placing the 2006/08 Commodity Price Boom into Perspective, Policy Research Working Paper No. 5371, The World Bank, July 2010.

http://www-wds.worldbank.org/external/default/WDSContentServer/IW3P/IB/2010/07/21/000158349_201007211 10120/Rendered/PDF/WPS5371.pdf

Bass, H. (2011). Finanzmärkte als Hungerverursacher? Studie für die Deutsche Welthungerhilfe e.V., Bonn 2011. http://www.welthungerhilfe.de/fileadmin/user_upload/Mediathek/Studie_Nahrungsmittelspekulation_Bass.pdf

Cashin, P., \& McDermott, C. J. (2002). The Long-Run Behavior of Commodity Prices: Small Trends and Big Variability. IMF Staff Papers, 49(2), 175-190. https://www.imf.org/external/pubs/ft/staffp/2002/02/pdf/cashin.pdf

Cheng, I., Kirilenko, A.,\&Xiong, W. (2012). Convective Risk Flows in Commodity Futures Markets.working paper, Princeton University. http://www.princeton.edu/ wxiong/papers/RiskConvection.pdf

Chilto, B. (2012). Speculators and Commodity Prices-Redux, February 24, 2012.http://www.cftc.gov/PressRoom/SpeechesTestimony/chiltonstatement022412

Committee on Homeland Security and Governmental Affairs United States Senate (2008). Testimony of Michael W. Masters Managing Member/Portfolio Manager Masters Capital Management, LLC.http://www.hsgac.senate.gov//imo/media/doc/052008Masters.pdf?attempt=2

Cohn, G. (2008). Co-President, Managing Director and COO of Goldman Sachs, New York, NY, in: U.S. Government Printing Office (2008), Senate Hearing 110-654, SUMMIT ON ENERGY. http://www.gpo.gov/fdsys/pkg/CHRG-110shrg45837/html/CHRG-110shrg45837.htm

Conrad, C. A. (2013). Auf dem Weg zu einer besseren Finanzmarktordnung. Journal of Banking andFinance, 61, 233-241. 
Deutsche Bundesbank (2006). Finanzderivate und ihre Rückwirkung auf die Kassamärkte. Monatsbericht, July, 55-68.

Domanski, D.,Heath, A. (2007). Financial investors and commodity markets.BIS Quarterly Review, March, 53-67.https://www.bis.org/publ/qtrpdf/r_qt0703g.pdf

Footwatch (2011). Die Hungermacher - wie Deutsche Bank, Goldman Sachs \& Co. auf Kosten der Ärmsten mit Lebensmittel spekulieren.

http://foodwatch.de/foodwatch/content/e10/e45260/e45263/e45318/foodwatch-Report_Die_Hungermacher_Okt-20 11_ger.pdf

Frenk, D. (2011). Review of Irwin and Sanders 2010 OECD Report, in: Institute for Agriculture and Trade Policy (Hrsg.).Excessive Speculation in Agriculture Commodities, Selected writings from 2008-2012, 43-49.http://www.iadb.org/intal/intalcdi/PE/2011/08247.pdf

Gilbert, C. L. (2010). How to Understand High Food Prices.Journal of Agricultural Economics, 61(2).http://econpapers.repec.org/article/blajageco/v_3a61_3ay_3a2010_3ai_3a2_3ap_3a398-425.htmhttp://dx.doi. org/10.1111/j.1477-9552.2010.00248.x

Hassler, U. (2003). Zeitabhängige Volatilität undinstationäre Zeitreihen. Wirtschaftsdienst, 83(12), 811-816.http://core.kmi.open.ac.uk/download/pdf/6697414.pdf

Henn, M. (2013). Kommentar zum Literaturüberblick zur Spekulation mit Agrarrohstoffen von Will et al., WEED, May 14, 2013. http://www2.weed-online.org/uploads/kommentar_literaturueberblick_agrarspekulation.pdf

Inamura, Y., Kimata, T., Kimura, T., \& Muto, T. (2011). Recent Surge in Global Commodity Prices - impact of financialization and Globally accommodative monetary conditions. Bank of Japan Review 2011 E 2, March. http://www.boj.or.jp/en/research/wps_rev/rev_2011/data/rev11e02.pdf

Irwin, S. H. (2013). Commodity index investments and food prices: does the "Masters Hypothesis" explain recent price spikes? Agricultural Economics, 44, 29-44.

http://onlinelibrary.wiley.com/doi/10.1111/agec.12048/abstracthttp://dx.doi.org/10.1111/agec.12048

Irwin, S. H., \&Sanders, D. R. (2010). The Impact of Index and Swap Funds on Commodity Future Markets, OECD Food, Agriculture and Fisheries Working Papers, 2. http://ideas.repec.org/p/oec/agraaa/27-en.htmlhttp://dx.doi.org/10.1016/j.eneco.2011.10.008

Irwin, S. H., \& Sanders, D. R. (2012). Testing the Masters Hypothesis in Commodity Futures Markets.Energy Economics, 34, 256-269.http://ideas.repec.org/a/eee/eneeco/v34y2012i1p256-269.html

Krugman, P. (2008, June 21). Calvo on commodities, New York Times, http://krugman.blogs.nytimes.com/2008/06/21/calvo-on-commodities/?_php=true\&_type=blogs\&_r=0.

Krugman, P. (2011, February 7). Speculation and Signatures, New York Times. http://krugman.blogs.nytimes.com/2011/02/07/signatures-of-speculation/

Lagi, M., Bar-Yam, Yav., Bertrand, K. Z., \& Bar-Yarn, Yan. (2011a). The Food Crises, A Quantitative Model of Food Prices Including Speculators and Ethanol Conversion, New England Complex Systems Institute. Cambridge. http://necsi.edu/research/social/food_prices.pdf

Lagi, M., Bar-Yam, Yav., Bertrand, K. Z., \& Bar-Yarn, Yan. (2011b). Economics of Food Prices and Crises. Cambridge MA. http://arxiv.org/pdf/1109.4859v1.pdf

Levin, C., \& Coburn, T. (2009).Excessive Speculation in the Wheat Market, United States Permanent Subcommittee on Investigations (2009), Excessive Speculation in the Wheat Market. Washington. http://www.levin.senate.gov/imo/media/doc/supporting/2009/PSI.WheatSpeculation.062409.pdf

Markowitz, H. (1952). Portfolio selection. Journal of Finance, 12. 77-91. https://www.math.ust.hk/ maykwok/courses/ma362/07F/markowitz_JF.pdfhttp://dx.doi.org/10.1111/j.1540-6261. 1952.tb01525.x

Masters, M. W. (2009). Testimony of Michael W. Masters Managing Member//Portfolio Manager Masters Capital Management LLC before the Commodity Future Trading Commission. http://www.cftc.gov/ucm/groups/public/@newsroom/documents/file/hearing080509_masters.pdf

Masters, M. W., \& White, A. K. (2008). The Accidental Hunt Brothers: How Institutional Investors are driving up Food and Energy Prices, 2008. http://www.loe.org/images/content/080919/Act1.pdf

Mayer, J. (2009). The Growing Interdependence between Financial and Commodity Markets. UNCTAD Discussion Paper, 195.http://unctad.org/en/Docs/osgdp20093_en.pdf 
Pagan, A., \& Schwert, C. (1990). Testing For Covariance Stationarity in Stock Market Data. Economics Letters, 33(2), 165-170. http://schwerts.com/el90_ps.pdfhttp://dx.doi.org/10.1016/0165-1765(90)90163-U

Peck, A. (1985). The Economic Role of Traditional Commodity Futures Markets. In: Anne Peck (Ed.). Future Markets: Their Economic Role (pp. 1-82.). Washington, D.C.: American Enterprise Institute for Public Policy Research. http://www.farmdoc.illinois.edu/irwin/archive/books/Futures-Economic/Futures-Economic preface.pdf

Petersen, V. J., Herlinghaus, A., \&Menrad, M. (2012). Risikomanagement auf globalen Agrarmärkten, Deutscher Raiffeisenverband e.V., DZ Bank 2012. http://www.raiffeisen.de/wp-content/uploads/downloads/2012/11/DRV-Brosch-Risiko_10_02.pdf

Phillips, P., \& Loretan, M. (1990).Testing Covariance Stationarity Under Moment Condition Failure with an Application to Common Stock Returns.Discussion Paper, 947. New Haven Conneticut: Cowles Foundation for Economic Research at Yale University. http://ideas.repec.org/p/cwl/cwldpp/947.html

Pies, I. (2012). Wirtschaftsethik konkret: Wie (un)moralisch ist die Spekulation mit Agrarrohstoffen? Diskussionspapier, 2012-15. Halle: Martin-Luther-Universität Halle-Wittenberg: Halle 2012. http://wcms.uzi.uni-halle.de/download.php?down=25900\&elem=2602684

Pies, I., Prehn, S., Glauben, T., \& Will, M. G. (2013). Kurzdarstellung Agrarspekulation, Diskussionspapier, 2013-2, Halle: Martin-Luther-Universität Halle-Wittenberg. http://wcms.uzi.uni-halle.de/download.php?down=27545\&elem=2636563

Pies, I., \& Will, M. G. (2013).Finanzmarktspekulation mit Agrarrohstoffen, Analyse und Bewertung aus wirtschaftsethischer Sicht, Diskussionspapier 2013-24. Halle: Martin-Luther-Universität Halle-Wittenberg. http://wcms.uzi.uni-halle.de/download.php?down=32275\&elem=2728397

Schlecker, M. (2014). Kointegrationsanalyse, Stationarität und Augmented-dickey-fuller-Test. http://www.matthias-schlecker.de/kointegrationsanalyse-stationaritaet-und-augmented-dickey-fuller-test

Schulze, P. M. (2004). Granger-Kausalitätsprüfung - Eine Anwendungsorientierte Darstellung. Arbeitspapier, 28. Mainz: Institut für Statistik und Ökonometrie, Johannes Gutenberg-Universität Mainz. http://www.statoek.vwl.uni-mainz.de/Arbeitspapier_Nr_28_Granger-Kausalitaetspruefung.pdf

Singleton, K. J. (2011). Investors Flows and the 2008 Boom/Bust in Oil Prices. http://www.stanford.edu/ kenneths/OilPub.pdf.

Stoll, H. R., \& Whaley, R. E. (2009).Commodity index investing and commodity future prices. http://www.cftc.gov/ucm/groups/public/@ swaps/documents/file/plstudy_45_hsrw.pdf

Tang, K., \&Xiong, W. (2012). Index Investment and the Financialization of Commodities. Financial Analyst Journal, 68 (6). 54-74. https://www.princeton.edu/ wxiong/papers/commodity.pdfhttp://dx.doi.org/10.2469/faj.v68.n6.5

U.S. Government Printing Office (2008). Senate Hearing 110-654, SUMMIT ON ENERG. http://www.gpo.gov/fdsys/pkg/CHRG-110shrg45837/html/CHRG-110shrg45837.htm

Weed (2013). Evidence on impact of commodity speculation. http://www2.weed-online.org/uploads/evidence_on_impact_of_commodity_speculation.pdf.

Will, M. G., Prehn, S., Pies, I., \& Glauben, T. (2012). Is financial speculation with agricultural commodities harmful or helpful? - A literature review of current empirical research. Discussion Paper, 2012-27. Halle: Martin-Luther-University Halle-Wittenberg. http://wcms.uzi.uni-halle.de/download.php?down=27388\&elem=2633683

\section{$(c)$ EY}

This work is licensed under a Creative Commons Attribution 3.0 License. 